NBER WORKING PAPER SERIES

\title{
A TEST OF THE INTERNATIONAL CAPM USING BUSINESS CYCLES INDICATORS AS INSTRUMENTAL VARIABLES
}

Bernand Dumas

Working Paper No. 4657

\section{NATIONAL BUREAU OF ECONOMIC RESEARCH 1050 Massachusetts Avenue Cambridge, MA 02138 \\ February 1994}

The author is on the faculty of the H.E.C. School of Management (France). He is Research Professor at Duke University (Fuqua School of Business), Research Associate of the NBER and Research Fellow of the CEPR and Delta. Some of the data used in this paper were generously supplied by Lombard Odier, by Jim Stock and by the Center for International Business Cycle Research at Columbia University. Sample GMM programs were provided to me by Wayne Ferson and Campbell Harvey. I acknowledge their help with thanks. Useful comments were received from Bruno Solnik, Michael Rockinger and participants and discussants at the pre-conference and the conference on the "Internationalization of Securities Markets", especially: Jeffrey Frankel, Gikas Hardouvelis, Bruce Lehmann, Richand Lyons, Campbell Harvey, Thierry Wizman, Charles Engel, Wayne Ferson and Vihang Errunza. Here again, I am grateful. This paper is part of NBER's research programs in Asset Pricing and International Finance and Macroeconomics. Any opinions expressed are those of the author and not those of the National Bureau of Economic Research. 


\title{
A TEST OF THE INTERNATIONAL CAPM USING BUSINESS CYCLES INDICATORS AS INSTRUMENTAL VARIABLES
}

\begin{abstract}
Previous work by Dumas and Solnik (1993) has shown that a CAPM which incorporates foreign-exchange risk premia (a so-called "international CAPM") is better capable empirically of explaining the structure of worldwide rates of return than does the classic CAPM. In the specification of that test, moments of rates of retum were allowed to vary over time in relation to a number of lagged "instrumental variables". Dumas and Solnik used instrumental variables which were endogenous or "internal" to the financial market (lagged world market portfolio rate of return, dividend yield, bond yield, short-term rate of interest). In the present paper, I use as instruments economic variables which are "external" to the financial market, such as leading indicators of the business cycles. This is an attempt to explain the behavior of the international stock market on the basis of economically meaningful variables which capture "the state of the economy". I find that the leading indicators put together by Stock and Watson (NBER working paper no. 4014, 1992) as predictors of the U.S. business cycle also predict stock returns in the U.S., Germany, Japan and the United Kingdom. These instruments lead again to a rejection of the classic CAPM and no rejection of the international CAPM.
\end{abstract}

\author{
Bemard Dumas \\ The Fuqua School of Business \\ Duke University \\ Durham, NC 27706 \\ and NBER
}




\section{Introduction}

Prevlous work by Dumas and Solntk (1993) has shown that a CAPM which incorporates forelgn-exchange rlsk premla (a so-called "International CAPM") is better capable empirically of explaining the structure of worldwide rates of return than is the classic CAPH. The test was performed on the conditiona version of the two competing CAPHs. By that is meant that moments of rates 0 return were allowed to vary over time in relation to a number of lagged

"Instrumental variables". Dumas and Solnik used instrumental var1ables which were endogenous or "Intermal" to the financial market (lagged world market portfolio rate of return, dividend yleld, bond yleld, short-cerm rate of Interest).

In the present paper, I ain to use as instruments economic variables whic are "external" to the financlal market, such as leading Indicators of business cycles. Th1s is an attempt to explain the behavior of the International stock market on the basis of economically meaningful varlables which capture "the state of the economy".

The stock market $1 \mathrm{~s}$ widely regarded as the best predictor of 1tself. A large body of emplrical work shows that asset prices are predictors of the future level of activity or, generally, the future level of economic varlables. ${ }^{1}$ Several leading Indexes of economic activity make use of this property of asset prices. ${ }^{2}$

1 Fama and Schwert (1977) show that asset returns predict inflation in the United States. Stambaugh (1988) has extracted the Information concerning future economic variables that is contained in bond prices. Several authors have observed that atock prices lead GNP (Fama(1981, 1990), Fama and Gibbons (1982), Geske and Roll (1983) and Barro (1990)).

2 The list of NBER leading indicators includes, besides exchange rates: (1) the yleld on a constant-maturity portfollo of 10 -year U.S. Treasury bonds, (11) the spread between the intrest rate on 6-month corporate paper and the 
It way, however, also be true that "external" varlables can serve to explain asset returns. Fama and French (1989) show that much of the movement In "Internal" variables is related to business conditions; for instance, the term structure spread peaks during recessions. Kandel and Stambaugh (1989) show that expected returns peak at the end of a recession and Harvey (1991b) shows that the ratio of conditional mean return to varlance is countercyclical. We show below that a particular set of leading Indicators (which does not include asset prices) predicts the stock markets of four economically developed countries with an in-sample $R^{2}$ which is comparable (and In some cases superior) to that of "internal" varlables.

From a theoretical standpaint, it should be clear that any intertemporal General-equilibrium model, such as the models of domestic or International business cycles that have appeared recently, ${ }^{3}$ would generate asset prices that would be functions of the state variables of the economy. In these models, the conditional expected values of rates of return would be functions of state varlables as well. Assuming that the mappling from state varlables to asset prices is invertible, conditlonal expected returns wust be functions of asset prices. This explains why the stock market predicts 1tself; a large enough number of asset prices can serve as proxy varlables for the state variables.

In the course of this substitution, however, the model has lost some of its

rate on 6-month U.S. Treasury b111s, (111) the spread between the yleld on a constant-matur1ty portfollo of 10 -year U.S. T-bonds and the yield on 1 -year U.S. T-bonds. See Stock and Watson (1989). The Department of Commerce 11st includes, besides money supply, the Standard and Poors 500 Industrials index (See Survey of Current Business. current issues).

3 Crucin1 (1993), Canova (1993) and Dumas (1992). 
empirical content since the link to the underlying physical economy has been severed. Even if one found that stock returns are related to stock prices in the theoretical way, that would still leave open the question of the contemporaneous relationship of this perfectly working stock market to the economy. Does the stock market move of 1ts own accord or does it remain in IIne with the conditions of physical production? More is achleved when underlying state variables are 1dentifled and expected returns are related to them, than when expected returns are related to asset prices. Th1s paper is a preliminary Investigation Into the nature of "the state of the economy", as revealed by the behavior of asset returns.

Capital Asset Pricing models can serve as a tool, or sift, in the Identification of state variables. First, one finds varlables that can serve to condition returns (1.e., that have some power to predict rates of return). Second, one verifies whether the conditional distribution satisfles some asset pricing restrictions. For Instance, can the first moments of returns be made to match time-varying risk premia bullt on second moments, as the conditional form of the classic CAPM would suggest they should? If not, either the model is Incorrect or the varlables have been 1mproperly chosen. The search for the relevant state varlables, which w1ll account for the time variability of asset returns, is also a search for the relevant model specification.

Th1s paper is organized as follows. Section 1 is a short reminder of the "pricing kernel" or marglnal-rate-of-substitution approach to CAPM tests. Section 2 explores the behavior of worldwide asset returns on the basis of U.S. Instrumental varlables. Section 3 does the same thing on the basis of country-specific instrumental variables. Section 4 concludes. 


\section{The "pricing kemel" methodolegy}

The "pricing-kerne1" method, or marginal-rate-of-substitution method, which was Initiated by Gallant and Tauchen (1989) and Hansen and Jagannathan (1991), was used in Bansal, Hsieh and Viswanathan (1992) and generalized by Duras and Solnik (1993) to test CAPMs.

\subsection{The international CAPM}

Let there be $L+1$ countries, a set of $-n+L+1$ assets $\ldots$ other than the measurement-currency deposit, -. comprised of $n$ equities or portfolios of equities, $L$ non-measurement-currency currency deposits and the world portfolio of equities which is the mth and last asset. The non-measurement-currency deposits are singled out by observing the above order in the 1 ist; $1 . e .$, they are the $(n+1)$ st to $(n+2)$ th assets.

The international Capital Asset Pricing model is Equation (14) In Adler and Dumas (1983):

$$
E\left[r_{j t} \mid \Omega_{t-1}\right]=\sum_{1-1}^{L} \lambda_{1, t-1} \operatorname{Cov}\left[r_{j t}, r_{n+1, t} \mid \Omega_{i-1}\right]+\lambda_{m, t-1} \operatorname{Cov}\left[r_{j t}, r_{m t} \mid \Omega_{t-1}\right]
$$

where $r_{j t}$ is the nominal return on asset or portfolio $\mathrm{J}, \mathrm{J}-1 \ldots \mathrm{m}$, from time $t$ - 1 to $t$, In excess of the rate of interest of the currency in which returns are measured, $r_{m t}$ is the excess return on the world market portfollo and $n_{t-1}$ is the information set which investors use in choosing their portfollos. The time-varying coefficients $\lambda_{1, t-1}, 1-1 \ldots L$, are the world prices of foreign exchange risk. The time-varying coefficient $\lambda_{m, t-1}$ is the world price of market risk. The model takes into account the fact that investors of different countries view returns differently. 
Equation (1.1) Is the result of an aggregation over the several categories of Investors. Equation (14) In Adler and Dumas (1983) provides an Interpretation of the prices of risk. $\lambda_{m}$ is a wealth-weighted harmonic mean of the nominal risk aversions of the Investors of the varlous countries .. the world nominal $r$ lsk aversion, as $1 t$ were. $\lambda_{1}$ is equal to $1-\lambda_{m}$ times the welght of country I In the world where a country's welght is determined by Its weslth times one minus its nominal risk tolerance.

By contrast, the classic CAPM Ignores Investor diversity and assumes, In effect, that everyone in the world translates returns Into consumption as do the residents of the reference currency country. Hence, no exchange-risk hedgIng premlum appears. In the above notations, the restriction of the International CAPM to the classic CAPM Is stated as:

$$
\lambda_{1, t-1}=0 \quad 1-1 \ldots L, \forall t
$$

In Dumas and Solnik (1993), a way has been found of writing the international CAPM In a parsimonious way, that minimizes the number of parameters to be estimated. Introduce $u_{t}$, the unanticipated component of the market's marglnal rate of substitution between nominal returns at date $t$ and at date $t-1 . u_{t}$ has the property that:

$$
E\left[u_{t} \mid n_{t-1}\right]=0 .
$$

Define $u_{t}$ as: 


$$
u_{t}-\lambda_{0, t-1}+\sum_{1-1}^{L} \lambda_{1, t-1} r_{n+1, t}+\lambda_{m, t-1} r_{m t} .
$$

And define $h_{\mathrm{jt}}$ as:

$$
h_{j t}-r_{j t}-r_{j t} u_{t} \quad j-1, \ldots m .
$$

Then, Dumas and Solnik (1993) show that the international CAPm (1) may be rewritten as:

$$
E\left[h_{j t} \mid \Omega_{t-1}\right]-0, \quad J-1, \ldots \text { m. }
$$

Equations (3) and (6) are the moment conditions used in the GMa estimation.

\subsection{Auxiliary assumptions of the econometric analysis}

In this subsection, we state two auxillary assumptions that are needed for econometric purposes. They are identical to the auxiliary assumptions used in Dumas and Solnik (1993).

Assumption $l$ of the empirical analysis: the information $n_{t-1}$ is generated by a vector of instrumental variables $z_{t-1}$.

$z_{t-1}$ is a row vector of $l$ predetermined instrumental variables which reflect everything that is known to the investor. One goal of this paper is to Identify the 1ist of $Z$ variables. Assumption 1 is a strong assumption which does not simply limit the information set of the econometrician; it limits the information set of the investors and, therefore, their strategy space. 
Next, we specify the way in which the market prices, $\lambda$, move over time. We assume that the variables, $Z$, can serve as proxies for the state varlables and that there exists an exact IInear relationship between the $\lambda$ s and the Zs:

Assumption 2:

$$
\lambda_{0, t-1}=-z_{t-1} \delta \text {. }
$$

$$
\begin{aligned}
& \lambda_{1, t-1}=z_{t-1} \phi_{1}, \quad 1-1, \ldots L \\
& \lambda_{m, t-1}-z_{t-1} \phi_{m} .
\end{aligned}
$$

here the $\delta s$ and $\phi s$ are time-1nvariant vectors of welghts which are estimated by GMM, under the moment conditions (3) and (6).

Given Assumption 2 and the definition $(1.10)$ of $u_{t}$, we have:

$$
u_{t}-z_{t-1} \delta+\sum_{1-1}^{L} z_{t-1} \phi_{1} r_{n+1, t}+z_{t-1} \phi_{\text {m }} r_{\text {unt }},
$$

with $u_{t}$ satisfying (3). Equation (8) serves to define $u_{t}$ from now on.

\subsection{Data}

We consider the monthly excess return on equity and currency holdings measured in a common currency, the U.S. dollar. The excess return on an equity market is the return on that market (cum dividend) translated into dollars, minus the dollar one-month nomlnally risk-free rate. The return on a currency holding is the one-month interest rate ${ }^{4}$ of that currency compounded by the exchange rate varlation relative to the U.S. dollar, minus the dollar one-

${ }^{4}$ These are Euro-currency Interest rates provided by Lombard Odier. 
month r1sk-free rate.

In this study, we take four countries Into account: Germany, the United KIngdow, Japan and the United States. More precisely, we consider elght assets In addition to the U.S. dollar deposit: the equity index of each country, ${ }^{5}$ Deutschemark deposit, a Pound Sterling deposit, a Yen deposit and the world Index of equities. In the CAPM, we Include only three exchange risk premla -. as many as we have exchange rates in the data set.

Avallable Index level data cover the perlod January 1970 to December 1991 which is a 264 data polnt serles. However, we work with rates of return and in earller work we needed to $\mathrm{Iag}$ the rate of return on the world index by one month in the instrumental-varlable set; that left 262 observations spanning March 1970 to December 1991. For the sake of comparab111ty, we use here the same time serles of returns.

As we consider below varlous instrument sets, preliminary statistics will be provided concerning rates of return and their predictablilty.

\section{U, Instrumental vartables}

We flrst Investigate a set of instruments common to all securities. We choose United States business cycle variables as a common set. In the next section, we explore country-speciflc varlables. The cholce of U.S. variables as a common set is Justifled by Figure I which plots colncldent indicators of the

\footnotetext{
5 Index.
} Index. See Harvey (I991a) for an appralsal of these Indexes. 
business cycle in the four countries of our sample from 1948-01 to 1993-06.6 It makes it plain that in most upturns and downturns the U.S. economy has lead the two European economles of our sample. Japan has had at the most two downturns since the war; the Unlted States has undergone downturns at about the same time. That the U.S. lead other economies is confirmed by Figure 2 which shows the crosscorrelogram of coincident Indicators between the U.S. and other countrles. ${ }^{7}$ Figure 2 reveals that U.S. lead Japan and Germany by at least twelve months and more strongly lead the U.K. with a lead time of four months approximately. That fact also explains Harvey's (1991a) finding that U.S. stock market -1nternal" variables are at least as good predictors of worldwide rates of return as are country-specific, "Internal" variables.

Below, we consider two sets of U.S. economic Indicators: the Main Economic Indicators of the OECD and the component indicators specifically selected by Stock and Watson (1992) to lead the U.S. cycles and predict recessions. Each time we consider a set of Instrumental variables, predictability of returns is assessed by OLS and conformity with the international and classic CAPMs is assessed by means of the Generalized Method of Moments (GMM).

\subsection{U.S. Main Economic Indicators (OECD)}

I extracted from the O.E.C.D. Main Economic Indicators (monthly data) the following varlables in their seasonally adjusted version for the twenty years of our rate-of-return sample: (1) the U.S. level of total inventories in

${ }^{6}$ These are the coincident indicators calculated by the Center for International Business Cycle Research (CIBCR), as an overall measure of the overall performance of a country's economy.

${ }^{7}$ These represent the correlation between the U.S. and other countries at various leads and lags, calculated after linear time detrending. 
manufacturing industries (noted INV), (11) U.S. residential construction put In place (RES), (111) U.S. total value of retall sales (RSAL), (iv) U.S. percentage unemployment out of the civilian labor force (UNMP), ${ }^{8}$ (v) U.S. commerclal bank loans (LOAN), (VI) the U.S. money supply M3 (noted M3). All of these were selected as being presumably "forward looking variables". Serles (iv) Is stationary naturally. Other series were included in their first difference form. Even though it is properly classified as an "Internal" variable, the lagged rate of return on the world market portfollo was added as an instrument in an attempt to capture potential lagged impacts of instruments on returns. 9

Table 1 contains some descriptive statistics on rates of return, Instrumental variables and their abllity to predict rates of return. I summarize in Table 2 the $\mathrm{R}^{2}$ s that have been achleved by Main Economlc Indicators (column 2) and, for purposes of comparison the $\mathrm{R}^{2} s$ that had been achleved by Dumas and Solnik (1593) by means of "Internal" variables (column 1). It is observed that the predictive power of the Main Economic Indicators is generally lower than was that of the "Internal" financlal variables. One variable has a consistent ability in predicting rates of return worldwide: the increase in U.S. Inventories in manufacturing industries, with a positive increase of that variable being followed by lower returns.

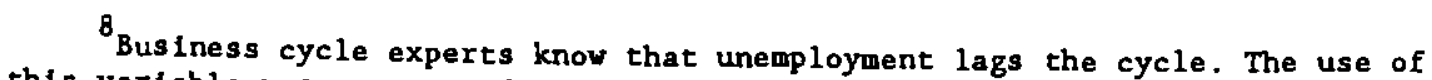
this varlable vas not a good idea but I refrained from making any changes to my original list for fear of accusations of data mining.

9

The coefficient of this predictor will be found to be insignificant. 
Using these variables as instruments, I proceed to estimate the international and the classic CAPLs. The results appear in Tables 3 and 4 respectively. The international CAPM ylelds a p-value of 0.0144 and is rejected. The classic CAPY produces a $p$-value of 0.0064 and is also rejected.

It is not clear whether it is legitimate to test a hypothesis when the unrestricted model (In this case the international CAPK) is itself rejected. A Newey-West test does not reject the hypothesis that exchange rate risk recelves a zero price $\left(\phi_{1}-0,1-1 \ldots L\right)$ (see Table 5, pvalue - 0.088).

\subsection{U.S. Leading Economic Indlcators (NBER)}

In a recent article, stock and Watson (1992) have proposed a leading Index (called XII2) which does not refer to financial varlables and is Instead constructed from the following leading indicators of the U.S. business cycle: ${ }^{10}$ (1) Housing authorizations (nev private housing) in levels (HSBP), 11 (11) Average weekly hours of production workers in manufacturing, in level form (LPHRM). (111) Vendor performance: percent of compantes reporting slower deliveries, in levels (IVPAC). (Iv) Manufacturers' unfilled orders in the

${ }^{10}$ All varlables are seasonally adjusted. In addition, stock and Watson (1992) Include the Trade Welghted Nominal Exchange Rate between the U.S. and other countrles as a leading indicator. We do not use it because it is a financial variable (although it obvlously has real effects).

11 observe that we use some of Stock and Watson's variebles in level form, others in first-difference form. The 1ssue of stetionarity arises. There is no evidence that the level varlables are non stationary. However, there is a question of consistency in the comparisons; here we have Housing authorlzations in levels, whereas Construction put in place -. an MEI variable - was used in first-difference form in section 2. Furcher investigation is needed. 
durable goods Industries, 1982 dollars, smoothed ${ }^{12}$ in growth rate form (MDU82), (v) the capacity ut1lization rate In manufacturing (Federal Reserve Board), In first difference form (IPXOCA), (VI) an Index of help-wanted advertising in newspapers (The Conference Board), in growth rates (LHELL).

Table 6 reports the results of multiple OLS (and heteroskedasticity corrected) regresslons of rates of return on these varlables. ${ }^{13}$ For purposes of comparison, the overall performance $\left(\mathrm{R}^{2} \mathrm{~s}\right)$ is transcribed In Table 2 . Thls set of Instruments predicts stock returns worldwide about as well as do the fInanclat or Internal varlables used by Dumas and Solntk. They predict currencles less well. The outstanding contribution to predictabllity is that of the Indlcator IVPAC (Vendor Performance) whose t-statistics in regressions of the varlous securlties rates of return are respectively: $-2.72,-4.23$, $-2.96,-4.05,-0.138,-1.42,-1.62,-4.30$. The slgns are as expected: an Increase in the number of firms reporting slower deliverles is followed by lower returns on securitles. The larger values of $t$ occur for stock returns. The forecasting of currencles presumably requires b!lateral instrumental varlables; U.S. business cycle varlables by themselves are insufficlent. Another valuable contribution is that of HSBP (Housing authorizations), also

${ }^{12}$ The sȩrles described as "smoothed" were passed through the fllter (1+ $\left.2 \mathrm{~L}+2 \mathrm{~L}^{2^{\text {the }}}+\mathrm{L}^{\mathrm{e}}\right)$.

${ }^{13}$ The Indicated varlables were used in a VAR form by stock and Watson to predict Increments in their Index of coincident Indicators (XCI). I use here the raw variables, In the form described, without the VAR form and without lags. I did reconstruct the Implied VAR coefficients that stock and Watson used but found that the VAR form predicts securlties returns with approximately the same degree of success as do the raw varlables. 
with the anticipated sign.

Many time serles (280 serles preclsely) were mined by Stock and Watson to select varlables, and thelr lags in order to make up an Index that predicta the three-month increments in their U.S. Index of colncident Indicators (XCI, defined in Stock and Watson (1989)). It turns out, however, that these varlables (without lags) also predict U.S. and other stock returns about as well as do internal variables. That is not the result of data mining. 14

There 1s, of course, an 1ssue concerning the preclse timing of releases of economic data. Internal varlables are observed in real time in the financlal markets whereas some economic varlables are released several weeks after the end of the month. In the statistical analysis we have simply used the data pertaining to month $t-1$ to predict rates of return over the month $(t-1, t)$. That procedure is not congruent with actual release dates. However, the varlable that is most effective in bringing about predictive performance 1s vendor performance IVPAC. IVPAC is released by the National Association of Purchasing Managers a mere two days after the end of the month.

Even if econorlc data are released with some delay by statistical agencles and would, therefore, be avallable to external observers at that time only, it Is also true that the Investors, whose Information set we are trying to

${ }^{14}$ The correlations between monthly securitles returns and one-month increments in XCI are as follows:

German stock market

British stock market

$-0.074$

Japanese stock market

$-0.073$

U.S. stock market

Deutschemark

0.046

British Pound

$-0.027$

Japanese Yen

$-0.075$

World stock

$-0.073$

0.026

-0.032 . 
represent, are not external observers and do not awalt actual releases. They enjoy the benefits of early estimates.

Furtherwore, financial market prices and flows of goods and services act ag aggregators of information faster than do statistical agencies. My goal in this article is not to show that external, economic varlables are superior in their predictive ability to internal, financlal varlables. I use them because I belleve that their message is more meaningful. I am comfortable with the Idea that news about economic variables may be "released" through the channel, inter alia, of financlal market prices. Even then, I am Interested in Identifying the relevant economic variables.

The reader may nonetheless wish to know how the results would have been affected by a different assumption on the timing of releases. In order to provide that Information to hin, I have shown In Table 2 the levels of $R^{2}$ s attalned when the Stock and Watson varlables are delayed further by one and also two months. Not surprisingly, the predictive performance for stock recurns deterlorates gradually. ${ }^{15}$ The predictive performance for currencles, which was poor in the first place, is not markedly affected.

Tables 7 and 8 report on the tests of the two CAPMs based on the Stock and Watson leading varlables. The overidentifying restrictions of the International CAPM are marginally accepted with a p-value of 0.067 and the

${ }^{15}$ In my opinion, the gradual deterioration in predictive power that. occurs confirms that earlier results were not pure chance and that tiere was scoe bone fide predictive power in the first place. 
classic CAPK is rejected with a p-value of $0.03 .^{16}$ A Newey-West test of the hypothesis of zero price on foreign exchange risk is reported in Table 5 and shows rejection ( $p$-value -0.0005 ). Fore1gn exchange risk premia are significant.

\section{Worldwide instrumental variables}

In tests of conditional CAPMs, it is crucial to predict well the market rate of return and, In tests of the international, conditional CAPM, it is 1mportant to predict well the rates of return on currencles. Exchenge rates are bilateral variables. Their prediction should not logically be based on unilateral instrumental variables, such as U.S. leading indicators. In thitsection. I consider instrumental varlables reflecting the business cycles of the four countries of our sample. I use leading indexes of the four countries' cycles simultaneously.

The Center for International Business Cycles Research (CIBCR) publ1shes every month a leading index of the business cycle for eleven countries. The growth rate of the Index provides advance warning of a growth cycle uptrun or downturn. ${ }^{17}$ I used the leading 1ndicators of Japan (JALDT), the United Kingdom (UKLDT), former West Germany (WGLDT) and the United States (USLDT), In

16 When the Stock-Watson instruments are lagged one month further, the international CAPM 1s marginally rejected ( $p-v a l-3.9 x)$ and the domestic CAPm is marginally accepted ( $\mathrm{p}-\mathrm{val}-9.17 \mathrm{z}$ ).

${ }^{17}$ Descriptions of various leading indicators are avallable in Lahiri and Moore (1991) and Moore (1992). 
their growth rate form, as instrumental varlables. The forecasting performance of the flve varlables (including a constant) is reported in Table 9. $R^{2}$ s are very low, of the order of $1 x$ or $2 x$. It did not seem worthwh1le to pursue a test of any CAPM.

The fact that a leading Index shows poor forecasting performance for stock returns does not preclude the component serles of the index from faring many times bettex. For Instance, the Stock and Watson XII2 Index predicts returns very poorly but we reported In Subsection 2.2 that 1 ts components provide the best forecasting basis that we have found so far. Th1s remark applies even more in the case of the CIBCR Indexes since they are meant to be qualitative predictors of upturns and downturns, not quantitative predictors of the subsequent movement in tho business cycle.

Accordingly, I have also Investigated the predictive abllity of the serles which compose the country leading Indexes of the CIBCR. For each country, I used as instruments every component serles that was avallable on a monthly bas1s. Then, e.g., German stock returns vere predicted on the basis of German Instruments alone but the Deutschemark/dollar return was predicted on the bas 1s of German and US. Instruments; the worldwide stock returns were predicted on the basis of all country instruments put together. In Table 2 a column, marked "LDT components", contalns the $\mathrm{R}^{2} \mathrm{~s}$ obtained by this method. The number of instruments is large; yet, the forecasting performance reached for stocks is no better than that of the NBER component serles. For currencles, the performance is better $\left(R^{2} s\right.$ of the order of 10X). However, due to the1r large number, these instruments cannot be used to test CAPMs by GM. Instruments ought to be selected in each country for the purpose of predicting increments in business cycle colncident indicators. This would be a 
replication of the stock and Watson procedure with worldwide data. Then, the selected instruments could be Investigated for the ability to forecast securities returns. This will be left for future research.

\section{Conclusion}

This preliminary Investigation was meant to highlight the links that exist between predicted activity levels and conditionally expected stock returns. The following conclusions emerge from it:

1. The nonfinancial leading Indicators selected by stock and Watson (1992) for the purpose of predicting United States business cycles seem to offer also some potential for the prediction of worldwide stock returns. Outstanding contributions to predictive power were made by the variables IVPAC (Vendor Performance) and HSBP (Housing authorizations). Furthermore, the signs of these variables' coefficients made intultive sense. IVPAC is an especially valuable predictor since its value is released a mere 48 hours after the end of the month.

11. Using the Stock and Watson Instrument set, the international, conditional CAPM was marginally not rejected while the classic, conditional CAPM was rejected.

1i1. Other sets of Instrumental varlables that I have tried so far (U.S. Main Economic Indicators, CIBCR country leading indexes) have not proven as successful both in regard to their power of prediction and in regard to their ability to discriminate between asset pricing models.

other, wore subtle clues could be gathered from the data and could polnt the way toward future research. The first issue that I would like to raise concerns the link between predictability of returns and the power of asset 
pricing tests. The OECD Main Economic Indlcators (MEIs), as used here, have lower predictive power than did the stock Watson leading series, while these serles in turn had a lower predictive abllity than did the "internal" varlables used by Dumas and Solntk and others (see Table 2). In tests of asset prices, the MEIs rejected both the classic and the International models, while the stock-Watson varlables rejected one model and marginally did not reject the other. In Dumas and Solnik (1993), the discrimination between the two asset pricing models was much sharper (the classic CAPH was rejected while the International one had a p-value of 22x). As we 1mprove the degree of predictabll1ty, should we expect better discrimination between models? since our goal is not to predict but to 1dentify state varlables of the economy and to determine which asset pricing model is correct, how much importance should we give to the predictive power (the $\mathrm{R}^{2}$ ) of the instruments?

The second issue concerns the cholce of instrumental varlables. In this respect, it is important to avold the pitfalls of data mining. That is the reason why I never modifled my 11 st of MEI Indicators and why I chose to work with the stock and Watson varlables which have been preselected to predict activity and not to predict stock returns. This defense against accusations of data mining is all the stronger as the correlations between stock returns and activitles levels are small (see footnote 14). As we attempt to predict vorldwide stock returns, should we be content to use U.S. varlables, such as those of Stock and Watson, on the grounds that the U.S. business cycle seems to lead other cycles? Or can we hope to attain greater predictibllity by using country-specific indicator varlables? If so, should these varlables be selected on the basis of their abllity to predict local levels of activity?

A third 1ssue that will deserve more scrutiny is the influence of time 
lags. Time lags are both of economic and statistical significance.

Econowically speaking, only Innovation in a data series is capable of constituting news. News are the primary moving force behind realized returns. It is not clear, however, to what extent the past information and the lag structure that were 1 dentifled as giving the best prediction of activity levels should also be relevant as determinants of conditionally expected returns. We did observe here (footnote 13) that the use of the stock and Watson lags did not improve the predictability of returns.

Finaliy, from the point of view of the statistical specification, Thierry Wizman will point out in his discussion that the levels, the first differences of Indicator variables and their first differences at different lags do not convey the same information concerning the stage of the business cycle the economy is in and do not have the same power to predict returns. How does one deterwine which specification is preferable for our purposes? 


\section{References}

Backus, D. K., P. J. Kehoe and F. E. Kydland, 1993, "International Business Cycles: Theory and Evidence," working paper, Stern School of Business (New York University).

Bansal, R., D. A. Hsleh and S. VIswanathan, 1992, "A New Approach to International Arbitrage Pricing," working paper, Duke University.

Barro, R, , 1990, "The Stock Market and Investment," Revlew of Flnanclal Studles, 3, 115-131.

Baxter, M. and M. J. Crucinl, 1993, Explalning Saving-Investment Correlations," Amertcan Econonlc Reylew, 83, 3, 416-436.

Canova, F., 1993, "Sources and Propagation of International Business Cycles: Common Shocks or Transmission?, CEPR working paper no 781.

Dumas, B., 1992, Dynamic Equllibrium and the Real Exchange Rate In a Spatlally Separated World," Revlew of Flnanclal Studies, 5, 153-180.

Fame, R., 1981, "Stock Returns, Real Activity, Inflation and Money," Amertcan Economic Reviey, 71, 545-565.

Fama, E. and K. Gibbons, 1982, Inflation, Real Returns and Capital Investwent, "Journal of Konetary Economics, 9, 297-323.

Fama, E. F. and K. R. French, 1989, "Business Condltions and Expected Returns on Stocks and Bonds," Journal of Financlal Economics, 25, 23-50.

Fama, E. F, and W. Schwert, 1977, "Asset Returns and Inflation," Journal of Financial Feonontes, 5, 115-146.

Frankel, J. A., 1982, "In Search of the Exchange RIsk Premium: A S1x-Currency Test of Mean-Varlance Efflclency," Joumal of International Money and FInance, $1,255-274$

Gallant, R. and G. Tauchen, 1989, "Sem1-non parametrlc Estimation of Conditionally Constralned Heterogeneous Processes: Asset Pricing Implications," Econometrica, 57, 1091-1120.

Geske, R. and R. Roll, 1983, The Konetary and Fiscal Linkage Between Stock Returns and Inflation," Journal of Elnance, 38, 1-33.

Hansen, L. P. and R. Jagannathan (1991), "Implications of Security Market Data for Models of Dynanic Economies," Joumal of Politlcal Economy, 99, 225-262.

Barvey, C. R., 1991a, "The World Price of Covariance RIsk," Journal of Enance, 46, 111-159.

Harvey, C, R., 1991b, "The Specification of Conditlonal Expectations," working paper, Fuqua School of Business, Duke University. 
Kandel, S. and R. F. Stambaugh, 1989, "Expectations and Volat1l1ty of LongHorizon Stock Returns," working paper 12-89, The Wharton School of the University of Pennsylvania.

Lahlri, K. and G. H. Moore, 1991, Leading Econom1c Indicators: New Approaches and Forecasting Records, Cambridge University Press.

Moore, G. H., 1992, Leading Indicators for the 1990s,

Stambaugh, R., 1988, "The Information in Forward Rates: Implications for Hodels of the Term Structure," Journal of Financial Econonlcs, 21, 41-69.

Stock, J, H, and M. W. Watson, 1992, "A Procedure for Predicting Recessions with Leading Indicators: Econometr1c Issues and Rcent Experience," NBER working paper no 4014 . 
Table 1

Summary statistics using U.S. MEI as Instrumental variables

number of obs- 262.00000

SECURITIES :

German stock market

British stock market

Japanese stock marke

U.S. stock market

Deutschemark

British Pound

Japanese Yen

World stock market

MEAN

OF EXCESS RETURN

0.0050726679

0.0065975649

0.0090457824

0.0024764962

0.0017136374

0.0017428969

0.0027198626

0.0031789237
STANDARD DEVIATION

OF EXCESS RETURN

0.077541166

0.065944529

0.046825699

0.034912228

0.031856602

0.033234643

0.043619171

INSTRURERTS :

$\begin{array}{lll} & \text { MEAN } & \text { STDEV } \\ \text { Cst } & 1.00000 & 0.00000\end{array}$

$\begin{array}{lll}x_{-1} & 0.0361454 & 0.521389\end{array}$

I界 0.005213800 .0105418

res $0.00644040 \quad 0.0253341$

rsal 0.006337190 .0132688

unmp $\quad 6.69847 \quad 1.38235$

loan 0.00774770 .00643937

43

0.00733305 .00353889

$\begin{array}{rr}1.0 & -0.15 \\ -0.15 & 1.0 \\ 0.11 & -0.21 \\ 0.026 & -0.086 \\ 0.13 & -0.18 \\ -0.054 & 0.14 \\ 0.054 & 0.11\end{array}$

CORRELATIONS

OLS WITH YETEROSKEDASTICITY CONSISTENT STANDARD ERRORS

(Securities returns regressed on instruments)

(Consistency is achleved by the Newey-West (NW) procedure)

German stock market

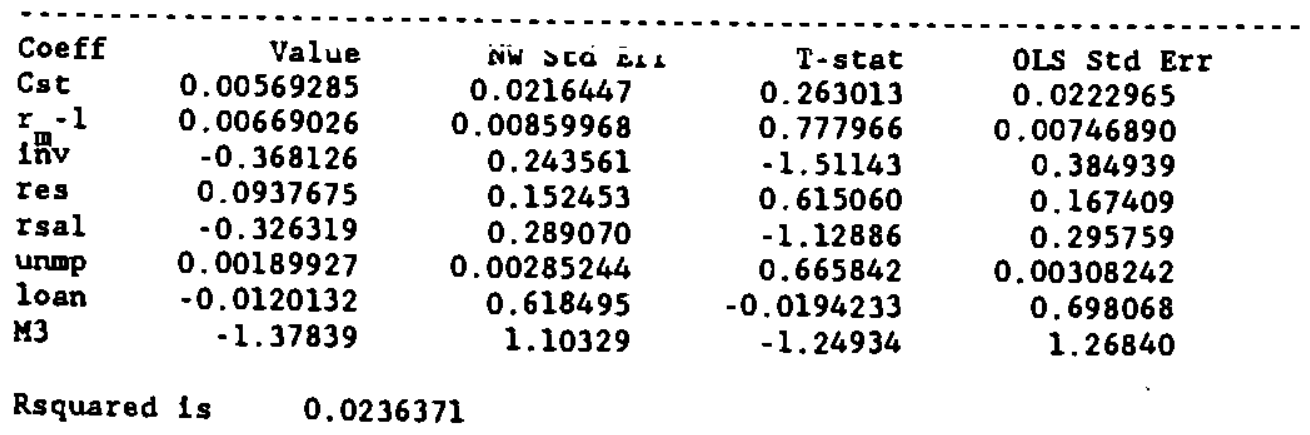

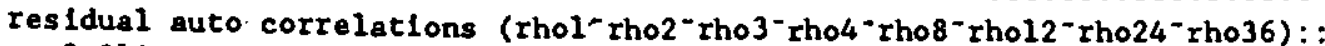
$-0.018$
$-0.0031$
0.067
0.059
$0.0027-0.041$
0.066
0.030 
Table 1 continued

D.X. stock market

$\begin{array}{lrrrr}\text { Coeff } & \text { Value } & \text { NW Std Err } & \text { Tostat } & \text { OLS Std Err } \\ \text { Cst } & 0.00456223 & 0.0230321 & 0.198082 & 0.0275204 \\ \text { r }^{-1} & 0.00693558 & 0.00955990 & 0.725486 & 0.00921879 \\ \text { Inv } & -0.553277 & 0.451608 & -1.22513 & 0.475126 \\ \text { res } & 0.126568 & 0.242514 & 0.521900 & 0.206631 \\ \text { rsal } & -0.553975 & 0.360443 & -1.53693 & 0.365052 \\ \text { unmp } & 0.00330507 & 0.00330871 & 0.998899 & 0.00380460 \\ \text { loan } & -0.684188 & 0.682991 & -1.00175 & 0.861619 \\ \text { M3 } & -1.29185 & 1.27644 & -1.01207 & 1.56557\end{array}$

\section{Rsquared is $\quad 0.0378930$}

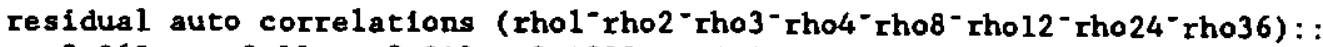
0.065
$-0.11$
0.043
0.0099
$-0.041$
$-0.017$
$0.085-0.067$

Japanese stock market

$\begin{array}{lrrrr}\text { Coeff } & \text { Value } & \text { NW Std Err } & \text { T-stat } & \text { OLS Std Err } \\ \text { Cst } & -0.00782489 & 0.0253743 & -0.308378 & 0.0233101 \\ \text { rm }^{-1} & 0.0136144 & 0.00992300 & 1.37201 & 0.00780844 \\ \text { Inv } & -0.862245 & 0.230546 & -3.74001 & 0.402438 \\ \text { res } & 0.0640068 & 0.174230 & 0.367371 & 0.175019 \\ \text { rsal } & -0.268500 & 0.357431 & -0.751195 & 0.309204 \\ \text { unmp } & 0.00178737 & 0.00316203 & 0.565262 & 0.00322255 \\ \text { loan } & 0.352924 & 0.598969 & 0.589220 & 0.729803 \\ \text { M3 } & 1.01683 & 1.20467 & 0.844073 & 1.32606\end{array}$

Rsquared is $\quad 0.0456416$

residual auto correlations (rho1"rho2-rho3"rho4-rho8-rhol2-rho24-rho36): $\begin{array}{llllllll}-0.057 & -0.019 & 0.036 & 0.030 & 0.062 & 0.075 & -0.015 & 0.051\end{array}$

U.S. stock msrket

\begin{tabular}{|c|c|c|c|c|}
\hline $\begin{array}{l}\text { Coeff } \\
\text { Cst } \\
\text { rnt }^{-1} \\
\text { 1nv } \\
\text { res } \\
\text { rsal } \\
\text { unmp } \\
\text { loan } \\
\text { M3 }\end{array}$ & $\begin{array}{r}\text { Value } \\
-0.00669039 \\
0.00231443 \\
-0.579509 \\
0.00226372 \\
-0.112179 \\
0.00337828 \\
-0.383116 \\
-0.935501\end{array}$ & $\begin{array}{c}\text { NW Std Err } \\
0.0168837 \\
0.00607610 \\
0.195591 \\
0.119716 \\
0.234005 \\
0.00223428 \\
0.444596 \\
0.823839\end{array}$ & $\begin{array}{r}\text { T-stat } \\
-0.396264 \\
0.380906 \\
-2.96286 \\
0.0189091 \\
-0.479386 \\
1.51203 \\
-0.861718 \\
-1.13554\end{array}$ & $\begin{array}{c}\text { OLS Std Err } \\
0.0165100 \\
0.00553053 \\
0.285037 \\
0.123962 \\
0.219002 \\
0.00228245 \\
0.516902 \\
0.939217\end{array}$ \\
\hline
\end{tabular}

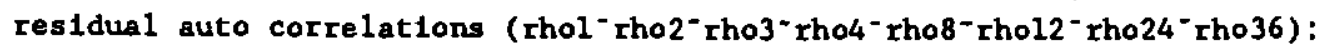

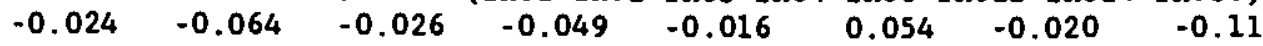


Table 1 continued

Deutschemark

$\begin{array}{lrrrr}\text { Coeff } & \text { Value } & \text { NW Std Err } & \text { T-stat } & \text { OLS Std Err } \\ \text { Cst } & 0.0258594 & 0.0111676 & 2.31557 & 0.0123199 \\ \text { rm }_{\text {m }} & -0.00801109 & 0.00404676 & -1.97963 & 0.00412691 \\ \text { Inv } & -0.385613 & 0.148917 & -2.58945 & 0.212696 \\ \text { res } & 0.0204019 & 0.0911840 & 0.223744 & 0.0925011 \\ \text { rsal } & -0.201447 & 0.159687 & -1.26152 & 0.163420 \\ \text { unmp } & -0.00275891 & 0.00157580 & -1.75080 & 0.00170318 \\ \text { loan } & 0.268681 & 0.402691 & 0.667214 & 0.385715 \\ \text { M3 } & -0.586607 & 0.605239 & -0.969215 & 0.700848\end{array}$

Rsquared is $\quad 0.0488795$

regidual auto correlations (rhol"rho2"rho3"rho4" rho8" rhol2" rho24"rho36):
0.028
$\begin{array}{lll}0.10 & -0.0038\end{array}$
$0.021-0.0049$
0.034
0.049
0.056

British Pound

\begin{tabular}{lrrrr} 
Coeff & Value & NN Std Err & T.gtat & \multicolumn{1}{c}{ OLS Std Err } \\
Cst & 0.0338504 & 0.0104436 & 3.24125 & 0.0111803 \\
r $^{-1}$ & -0.00303430 & 0.00378204 & -0.802292 & 0.00374519 \\
Inv & -0.233203 & 0.109419 & -2.13128 & 0.193023 \\
res & 0.0888226 & 0.0846396 & 1.04942 & 0.0839452 \\
rgal & -0.220981 & 0.136461 & -1.61937 & 0.148305 \\
unip & -0.00339392 & 0.00139092 & -2.44005 & 0.00154564 \\
loan & 0.222244 & 0.318936 & 0.696829 & 0.350038 \\
M3 & -1.21933 & 0.543510 & -2.24344 & 0.636023
\end{tabular}

Rsquared is $\quad 0.0592174$

residual auto correlations (rhol'rho2-rho3-rho4-rhos-rhol2-rho24-rho36): $\begin{array}{llllllll}0.066 & 0.067 & -0.017 & 0.028 & -0.084 & -0.047 & 0.037 & 0.00080\end{array}$

Japenese Yen

\begin{tabular}{lrrrr} 
Coeff & \multicolumn{1}{c}{ Value } & NW Std Err & Trstat & OLS Std Err \\
Cst & 0.0110907 & 0.0120695 & 0.918900 & 0.0118473 \\
r.1 & -0.000429227 & 0.00397897 & -0.107874 & 0.00396862 \\
Inv & -0.365841 & 0.111626 & -3.27740 & 0.204538 \\
res & 0.113531 & 0.0832779 & 1.36328 & 0.0889533 \\
rsal & -0.213294 & 0.169312 & -1.25977 & 0.157152 \\
unmp & -0.000364428 & 0.00168879 & -0.215793 & 0.00163785 \\
loan & 0.00795930 & 0.290915 & 0.0273595 & 0.370921 \\
M3 & -0.470191 & 0.575398 & -0.817156 & 0.673967
\end{tabular}

residual auto correlations (rho1"rho2"rho3-rho4" rho8-rho12-rho24-rho36):

$\begin{array}{llllllll}0.048 & 0.041 & 0.080 & 0.068 & -0.0037 & 0.096 & -0.051 & -0.052\end{array}$


Table 1 continued

Vorld stock market.

$\begin{array}{lrrrr}\text { Coeff } & \text { Value } & \text { NH Std Err } & \text { T-stat } & \text { OLS Std Err } \\ \text { Cst } & -0.00802493 & 0.0160887 & -0.498793 & 0.0153149 \\ r_{\text {m }}-1 & 0.00598386 & 0.00545754 & 1.09644 & 0.00513018 \\ \text { Inv } & -0.622000 & 0.183153 & -3.39607 & 0.264404 \\ \text { res } & 0.0297202 & 0.117849 & 0.252190 & 0.114989 \\ \text { rsal } & -0.293711 & 0.211799 & -1.38674 & 0.203149 \\ \text { unwp } & 0.00311797 & 0.00202408 & 1.54044 & 0.00211723 \\ \text { loan } & -0.00729195 & 0.440082 & -0.0165695 & 0.479484 \\ \text { M3 } & -0.672124 & 0.776432 & -0.865657 & 0.871228\end{array}$

Ren

residual auto correlations (rhol'rho2 rho3-rho4-rhos rho12-rho24-rho36):

$\begin{array}{llllllll}-0.011 & -0.049 & 0.021 & -0.041 & -0.013 & 0.067 & 0.0098 & -0.095\end{array}$ 
Table 2

Summary of predictive abllity of instruments

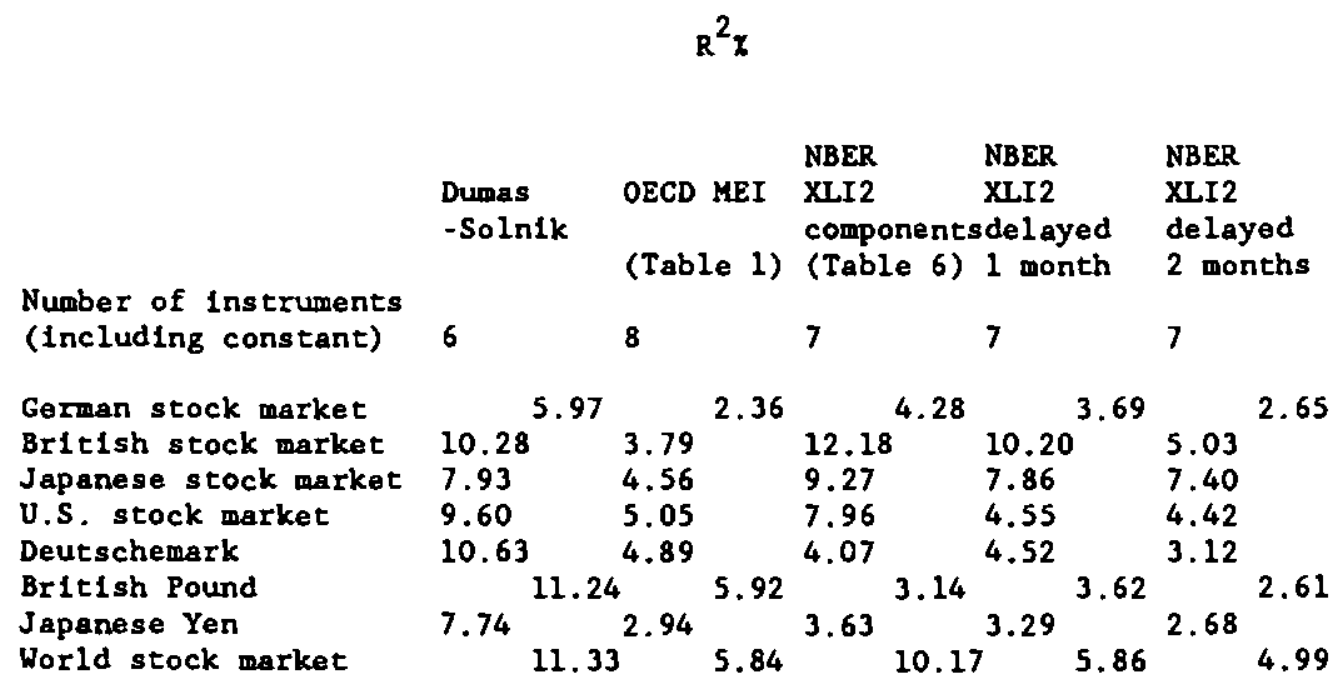

Table 2 continued

$\begin{array}{ll}\text { CIBCR } & \text { CIBCR } \\ \text { country } & \text { LDT } \\ \text { LDTs } & \text { components } \\ \text { (Table 9) } & \end{array}$

Number of instruments (Including constant)

(Number of instruments varies)

German stock market

British stock market

Japanese stock market

U.S. stock market

Deutschemark

British Pound

Japanese Yen

World stock market

$\begin{array}{ll} & 2.76 \\ 0.50 & \\ 0.82 & \\ 0.93 & \\ 2.23 & \\ & 0.72 \\ 0.06 & \\ & 0.90\end{array}$

2.76

2.84
6.43
8.93
6.75

2.19

(7)

(10)

6.75

10.39

9.56

(16)
(7) $18.26^{(16)}(30)$ 
Table 3

Estimation of the international CAPH with U.S. MEI as Instrumental varlables

number of observation- 262.00000

number of factors- 4.0000000

degrees of freedom- 32.000000

\begin{tabular}{|c|c|c|c|}
\hline \multicolumn{4}{|c|}{ 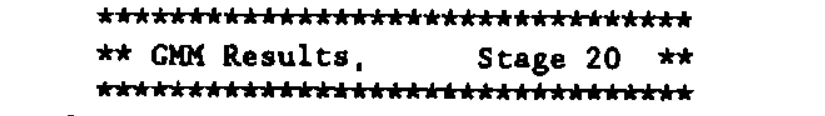 } \\
\hline Coeff & Value & Std Err & T-stat \\
\hline LIneer & form for $\lambda_{0}$ & (see Bquation & $(7))$ \\
\hline $\begin{array}{l}\text { Cst } \\
r_{\text {m }}-1 \\
\text { Inv } \\
\text { res } \\
\text { rsal } \\
\text { unmp } \\
\text { loan } \\
\text { M3 }\end{array}$ & $\begin{array}{r}-0.7624 \\
0.0567 \\
27.9459 \\
2.1540 \\
-6.2960 \\
0.0185 \\
-2.7934 \\
-34.0587\end{array}$ & $\begin{array}{r}0.3710 \\
1.3231 \\
15.0797 \\
2.1545 \\
4.9054 \\
0.0055 \\
9.7046 \\
14.2208\end{array}$ & $\begin{array}{r}-2.0553 \\
0.0428 \\
1.8532 \\
0.9998 \\
-1.2835 \\
3.3873 \\
-0.2878 \\
-2.3950\end{array}$ \\
\hline
\end{tabular}

Linear forms for market prices of risk, $\lambda_{m, t-1}$ and $\lambda_{1, t-1}$

Cst

$\begin{array}{rrrr}\lambda m, t-1 & 53.8784 & 24.1627 & 2.2298 \\ \lambda 1, t-1 & 45.0855 & 20.5153 & 2.1977 \\ \lambda 2, t-1 & -30.7942 & 20.7468 & -1.4843 \\ \lambda 3, t-1 & -23.0563 & 9.9523 & -2.3167\end{array}$

$\operatorname{rm}(-1)$

$\lambda \mathbf{m}, \mathrm{t}-1$

$\lambda 1, t-1$

$-160.2995$

87.9048

$\lambda 2, t-1$

39.4347

86.3428

83.4154

$-1.8565$

$\lambda 3, t-1$

17.2105

75.9711

1.0538

34.7671

Inv

$\lambda \mathrm{m}, \mathrm{t}-\mathrm{l} \quad-1390.1074$

$\lambda 1, t-1 \quad 718.7262$

733.0540

727.4729

561.8708

256.9847

$-1.8963$

$-229.0456$

$-148.8943$

$-0.4076$

$\lambda 3, t-1$

res

$\lambda m, t-1$

$\lambda 1, t-1$

$-206.5363$

78.9526

$\lambda 2, t-1$

140.8913

7.2748

138.6434

$-1.4897$

159.1203

169.2117

0.4962

$\lambda 3, t-1$

82.5645

0.8326

0.0881 


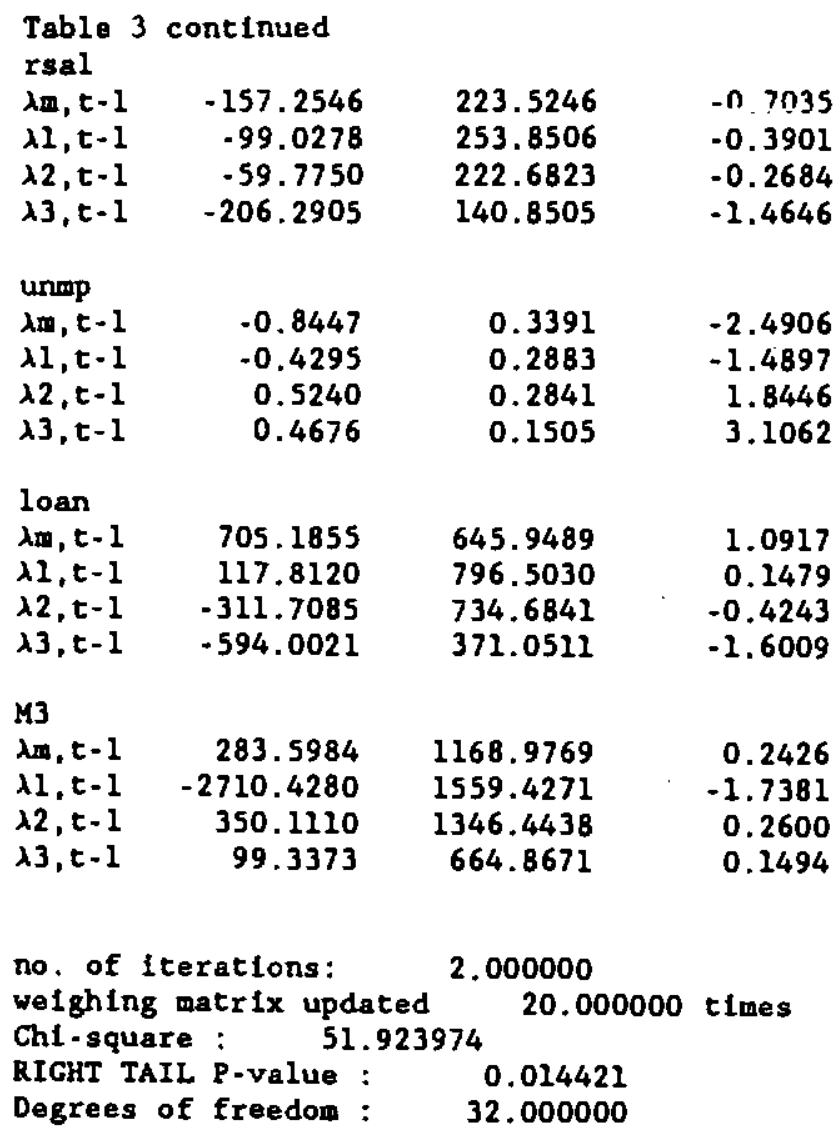


Table 4

Estimation of the classic CAPM with U.S. MEI as instrumental variables

nbre observation= 262.00000000

nbre facteurs- 1.00000000

degrees of freedom- 56.00000000

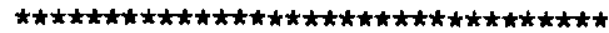

$\star \star \quad$ GMY Results, Stage $31 \star \star$

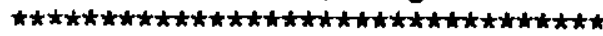

Coeff Value Std Err T-stat

Linear form for $\lambda_{0, t-1}$ (see Equation (7))

Cst $\quad-0.0590 \quad 0.1727 \quad-0.3416$

$r_{\mathrm{m}}-1 \quad-0.2638 \quad 0.5272 \quad-0.5003$

1藏 $\quad 8.0625 \quad 11.0876 \quad 0.7272$

$\begin{array}{llll}\text { res } & 1.4246 & 1.2198 & 1.1679\end{array}$

$\begin{array}{llll}\text { rsal } & -6.7746 & 3.1070 & -2.1804\end{array}$

unmp $\quad 0.0023 \quad 0.0026 \quad 0.8853$

loan $\quad-0.3844 \quad 3.0409 \quad-0.1264$

M3 $\quad-2.0035 \quad 7.5628 \quad-0.2516$

Linear form of market price of coveriance risk, $\lambda_{m, t-1}$

$\begin{array}{lrrr}\text { Cst } & -2.0280 & 7.9695 & -0.2545 \\ r_{\mathrm{m}}-1 & 14.2907 & 30.0824 & 0.4751 \\ \text { Inv } & -344.1557 & 126.6979 & -2.7163 \\ \text { res } & 113.9686 & 72.0067 & 1.5828 \\ \text { rsal } & -343.5483 & 121.5828 & -2.8256 \\ \text { unmp } & 0.1899 & 0.1152 & 1.6485 \\ \text { loan } & -81.3205 & 306.1997 & -0.2656 \\ \text { M3 } & -379.7604 & 541.0834 & -0.7019\end{array}$

no. of 1terations: $\quad 4.000000$

weighing matrix updated 31.000000 times

Ch1-square : 85.755252

RIGKT TAIL P-value : 0.006427

Degrees of freedom : $\quad 56.000000$ 
Table 5

Tests of hypotheses

Statistics in this table test the hypothesis: $\phi_{,}-0,1-1,2,3$ against the alternative that the international CAPH holds. The various tests differ only in the set of the instrumental variables used.

Instruments Specification

U.S. MEI

8 instr.

U.S. NBER

7 ingtr.

Linear $x^{2}$ difference degrees $\quad \begin{aligned} & \text { p-value } \\ & \text { of freedom }\end{aligned}$
750564
24
0.088

33.826590

86.702953

$-39.961045$

46.741908
21

0.001 
Table 6

Summary statistics with U.S. NBER varlables as instruments

\begin{tabular}{lrrrrrrrr} 
INSTRUMENTS & \multicolumn{1}{c}{ MEAN } & \multicolumn{1}{c}{ STDEV } & \multicolumn{1}{l}{ CORRELATIONS } \\
cst & 1.00000 & 0.00000 & & & & & & \\
hsbp & 121.004 & 32.6542 & 1.0 & 0.34 & 0.49 & 0.44 & 0.41 & 0.48 \\
lphrm & 40.2859 & 0.607544 & 0.34 & 1.0 & 0.45 & 0.38 & 0.30 & 0.23 \\
Ivpac & 53.3844 & 13.0493 & 0.49 & 0.45 & 1.0 & 0.58 & 0.23 & 0.29 \\
mdu82 & 0.00139399 & 0.0102974 & 0.44 & 0.38 & 0.58 & 1.0 & 0.27 & 0.31 \\
Ipxmca & -0.0164122 & 0.772366 & 0.41 & 0.30 & 0.23 & 0.27 & 1.0 & 0.49 \\
lhell & -0.000517679 & 0.0316811 & 0.48 & 0.23 & 0.29 & 0.31 & 0.49 & 1.0
\end{tabular}

OLS UITH UETRROSKEDASTICITY CONSISTENT STANDARD ERRORS

(Securities returns regressed on instruments)

(Consistency is achleved by the Newey-West (NW) procedure)

German stock market

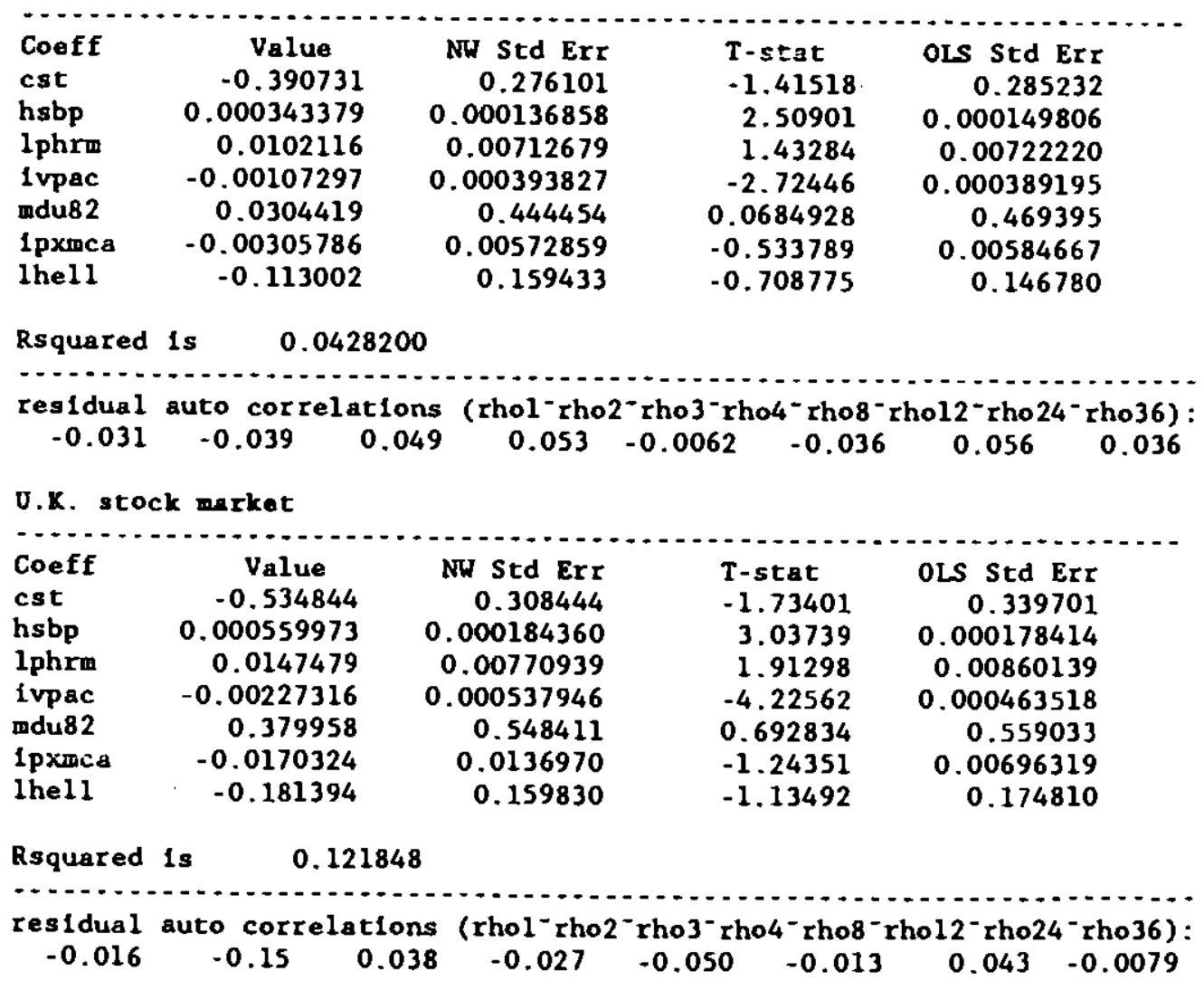


Table 6 continued

Japanese stock market

\begin{tabular}{lcrrr} 
Coeff & Value & NW Std Err & \multicolumn{1}{c}{ T-stat } & OLS Std Err \\
cst & -0.253508 & 0.320174 & -0.791781 & 0.293657 \\
hsbp & 0.000750459 & 0.000148571 & 5.05119 & 0.000154231 \\
lphris & 0.00563301 & 0.00822220 & 0.685097 & 0.00743553 \\
ivpac & -0.00102859 & 0.000346998 & -2.96424 & 0.000400692 \\
mdu82 & -0.288754 & 0.449197 & -0.642822 & 0.483261 \\
lpxorca & -0.00251334 & 0.00529847 & -0.474353 & 0.00601938 \\
lhell & -0.166150 & 0.141414 & -1.17492 & 0.151116 \\
Rsquared 1s & 0.0926722 & & &
\end{tabular}

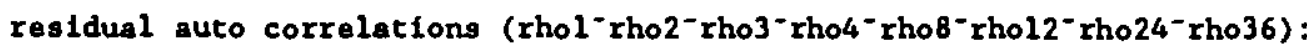
$\begin{array}{llllllll}-0.020 & -0.071 & -0.0020 & -0.011 & 0.043 & 0.073 & 0.0095 & 0.077\end{array}$

D.s. stock markat

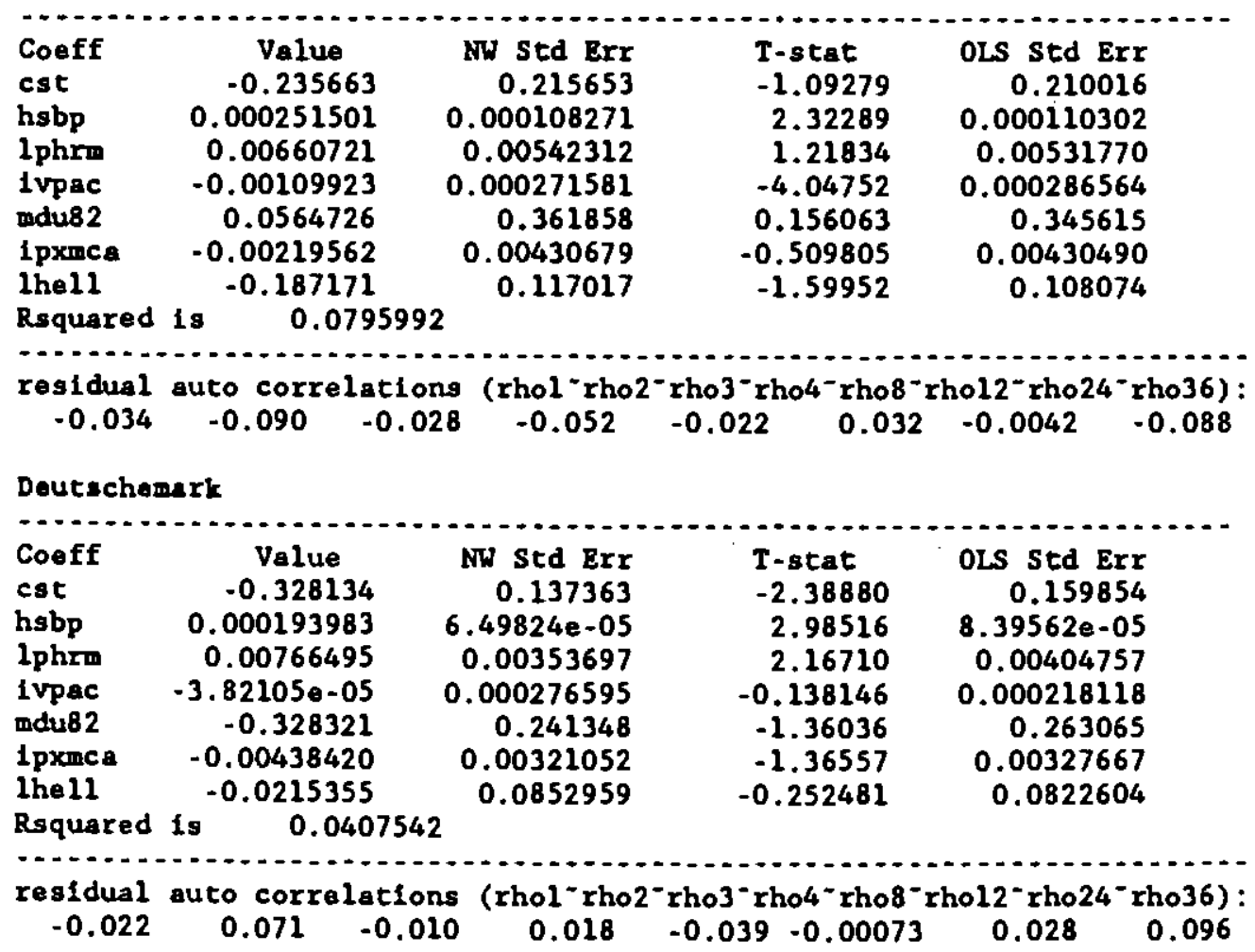


Table 6 continued

British Pound

\begin{tabular}{lcrrr} 
Coeff & Value & NW Std Err & \multicolumn{1}{c}{ T-stat } & \multicolumn{1}{c}{ OLS Std Err } \\
cst & -0.332575 & 0.133099 & -2.49870 & 0.146574 \\
hsbp & 0.000103983 & $5.95071 \mathrm{e}-05$ & 1.74741 & $7.69820 \mathrm{e}-05$ \\
lphrm & 0.00828977 & 0.00341368 & 2.42840 & 0.00371133 \\
Ivpac & -0.000231653 & 0.000163528 & -1.41660 & 0.000199999 \\
mdu82 & 0.0712808 & 0.212960 & 0.334714 & 0.241212 \\
Ipxmca & -0.000255775 & 0.00267844 & -0.0954940 & 0.00300448 \\
lhell & 0.0733277 & 0.0714012 & -1.02698 & 0.0754270 \\
Rsquared is & 0.0313697 & & &
\end{tabular}

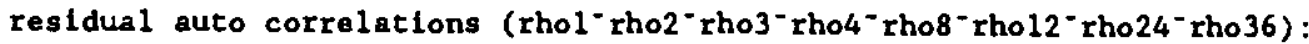

$\begin{array}{llllllll}0.056 & 0.073 & -0.016 & 0.036 & -0.093 & -0.046 & -0.011 & 0.038\end{array}$

Japanese Yen

\begin{tabular}{lcrrr} 
Coeff & Value & NW Std Err & \multicolumn{1}{c}{ T-stat } & \multicolumn{1}{c}{ OLS Std Err } \\
cst & -0.159703 & 0.166350 & -0.960047 & 0.152527 \\
hsbp & 0.000187078 & $6.24738 \mathrm{e}-05$ & 2.99450 & $8.01082 \mathrm{e}-05$ \\
lphrm & 0.00389288 & 0.00423289 & 0.919674 & 0.00386205 \\
Ivpac & -0.000316085 & 0.000194594 & -1.62433 & 0.000208121 \\
mdu82 & -0.134085 & 0.244464 & -0.548487 & 0.251008 \\
Ipxmca & -0.00347325 & 0.00299366 & -1.16020 & 0.00312649 \\
lhell & 0.0734632 & 0.0826545 & 0.888798 & 0.0784901 \\
Rsquared is & 0.0362787 & & &
\end{tabular}

- -

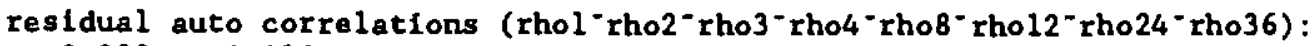

$\begin{array}{llllllll}0.039 & 0.018 & 0.065 & 0.067 & -0.015 & 0.094 & -0.061 & -0.030\end{array}$

World stock market

\begin{tabular}{|c|c|c|c|c|}
\hline $\begin{array}{l}\text { Coeff } \\
\text { cst } \\
\text { hsbp } \\
\text { lphrm } \\
\text { ivpac } \\
\text { mdu82 } \\
\text { ipxica } \\
\text { lhell } \\
\text { Rsquared }\end{array}$ & $\begin{array}{r}\text { Value } \\
-0.304620 \\
0.000392649 \\
0.00789062 \\
-0.00108092 \\
-0.0322675 \\
-0.00401874 \\
-0.172625 \\
\text { is } \quad 0.101\end{array}$ & $\begin{array}{r}\text { NW Std Err } \\
0.201082 \\
9.90945 \mathrm{e}-05 \\
0.00511004 \\
0.000251444 \\
0.322532 \\
0.00432539 \\
0.102169\end{array}$ & $\begin{array}{l}\text { T-stat } \\
-1.51490 \\
3.96237 \\
1.54414 \\
-4.29886 \\
-0.100044 \\
-0.929105 \\
-1.68960\end{array}$ & $\begin{array}{r}\text { OLS Std Err } \\
0.193269 \\
0.000101506 \\
0.00489366 \\
0.000263713 \\
0.318056 \\
0.00396162 \\
0.0994560\end{array}$ \\
\hline $\begin{array}{r}\text { esidual } \\
0.0092\end{array}$ & -0.096 & $4-0.048$ & 310.05 & 0.015 \\
\hline
\end{tabular}


Table 7

Estimation of the International CAPM wIth U.S. NBER Instrumental varlables

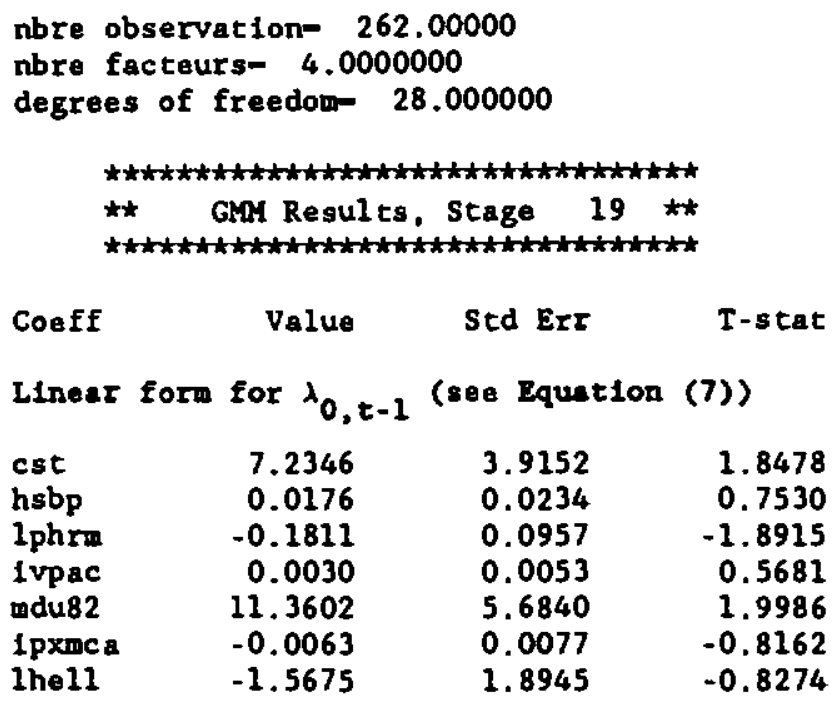

300.3837

230.8744

233.2194

151.6363

$-0.8145$

$-1.8265$

1.5489

$-0.2166$

hsbp

Am, t-1

$\lambda 1, t-1$

$\lambda 2, t-1$

$\lambda 3, t-1$

6.3348

$-1.7197$

$-1.0261$

2. 2875

2.0582

1.8737

1.6096

0.9770

3.0779

$$
-0.9178
$$$$
-0.6374
$$

lphrw

im, $t-1$

$\lambda 1, t-1$

$\lambda 2, t-1$

$\lambda 3, t-1$

4.0333

11.0753

$-7.8050$

0.9961

I vpac

Am, t-1

$\lambda 1, t-1$

$\lambda 2, t-1$

$\lambda 3, t-1$

0.4265

$-0.1739$

$-0.7289$

$-0.4764$
7.6146

5.9827

5.9297

3.8104

0.3275

0.4019

0.3564

0.1738 


\begin{tabular}{|c|c|c|c|}
\hline$\lambda \mathbf{m}, t-1$ & -1518.8104 & 512.2532 & -2.9650 \\
\hline$\lambda 1, t-1$ & 762.5102 & 432.8288 & 1.7617 \\
\hline$\lambda 2, t-1$ & 583.1863 & 426.5617 & 1. 3672 \\
\hline$\lambda 3, t-1$ & -105.5570 & 259.2887 & -0.4071 \\
\hline \multicolumn{4}{|l|}{ Ipxmca } \\
\hline$\lambda m, t-1$ & -0.6235 & 0.4303 & -1.4488 \\
\hline$\lambda 1, t-1$ & 1.1746 & 0.5937 & 1.9785 \\
\hline$\lambda 2, t-1$ & -0.2372 & 0.4885 & -0.4856 \\
\hline$\lambda 3, t-1$ & 0.3153 & 0.1770 & 1.7812 \\
\hline \multicolumn{4}{|l|}{ Ihell } \\
\hline$\lambda m, t-1$ & -200.9777 & 114.8282 & -1.7502 \\
\hline$\lambda 1, t-1$ & -227.7343 & 111.1008 & -2.0498 \\
\hline$\lambda 2, t-1$ & 354.0376 & 126.1874 & 2.8056 \\
\hline$\lambda 3, t-1$ & -171.5884 & 56.9768 & -3.0116 \\
\hline \multicolumn{4}{|c|}{ no. of iterations: $\quad 2.000000$} \\
\hline \multicolumn{4}{|c|}{$\begin{array}{ll}\text { welghing matrix updated } & 19.0000 \\
\text { Chi-square : } & 39.961045\end{array}$} \\
\hline $\begin{array}{l}\text { RIGHT T } \\
\text { Degrees }\end{array}$ & $\begin{array}{l}\text { IL P-value: } \\
\text { of freedon : }\end{array}$ & $\begin{array}{r}0.066658 \\
28.000000\end{array}$ & \\
\hline
\end{tabular}


Table 8

Estimation of the classic GAPM with U.S. NBER Instrumental variables

nbre observation- 262.00000000

nbre facteurs- 1.00000000

degrees of Ereedor- 49.00000000

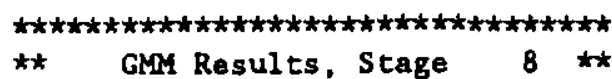

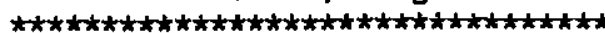

Coefe Value Std Err T-stat

Linear form for $\lambda_{0, t-1}$ (see Equetion (7))

$\begin{array}{lrrr}\text { cst } & 2.5886 & 1.8490 & 1.4000 \\ \text { hsbp } & 0.0087 & 0.0162 & 0.5388 \\ \text { lphrm } & -0.0709 & 0.0469 & -1.5126 \\ \text { 1vpac } & 0.0056 & 0.0037 & 1.5079 \\ \text { mdu82 } & 1.5476 & 3.2085 & 0.4823 \\ \text { 1pxmca } & -0.0082 & 0.0051 & -1.6022 \\ \text { lhel1 } & -1.4689 & 1.0460 & -1.4044\end{array}$

Linear form of market price of coveriance risk, $\lambda_{m, t-1}$

$\begin{array}{lrrr}\text { cst } & -124.5130 & 117.8852 & -1.0562 \\ \text { hsbp } & 2.4277 & 0.7155 & 3.3930 \\ \text { lphrd } & 3.3990 & 2.9848 & 1.1388 \\ \text { lvpac } & -0.6296 & 0.1319 & -4.7728 \\ \text { mdu82 } & 61.8821 & 202.6053 & 0.3054 \\ \text { lpxemcs } & 0.1011 & 0.1378 & 0.7339 \\ \text { lhell } & -99.3850 & 44.9423 & -2.2114\end{array}$

no, of 1terations: $\quad 4.000000$

welghing matrix updated 8.000000 times

Chl-square : $\quad 69.235898$

RIGHT TAIL P-value : 0.029985

Degrees of freedor: 49.000000 
Table 9

Summary statistics with CIBCR's country leading indexes as instruments INSTRURENS :

$\begin{array}{lcccccc} & \text { MEAN } & \text { STDEV } & \text { CORRELATIONS } & & \\ \text { CSE } & 1.000000 & 0.000000 & & & & \\ \text { JALDT } & 0.003146 & 0.013503 & 1.00 & 0.29 & 0.37 & 0.25 \\ \text { UKIDT } & 0.001078 & 0.006056 & 0.29 & 1.00 & 0.23 & 0.22 \\ \text { WGLDT } & 0.001533 & 0.005653 & 0.37 & 0.23 & 1.00 & 0.28 \\ \text { USLDT } & 0.002531 & 0.009265 & 0.25 & 0.22 & 0.28 & 1.00\end{array}$

OLS UITH HETEROSKEDASTICITY CONSISTENT STANDARD ERRORS

(Securities returns regressed on instruments)

(Consistency is achleved by the Newey-West (NW) procedure)

Cerman stock market

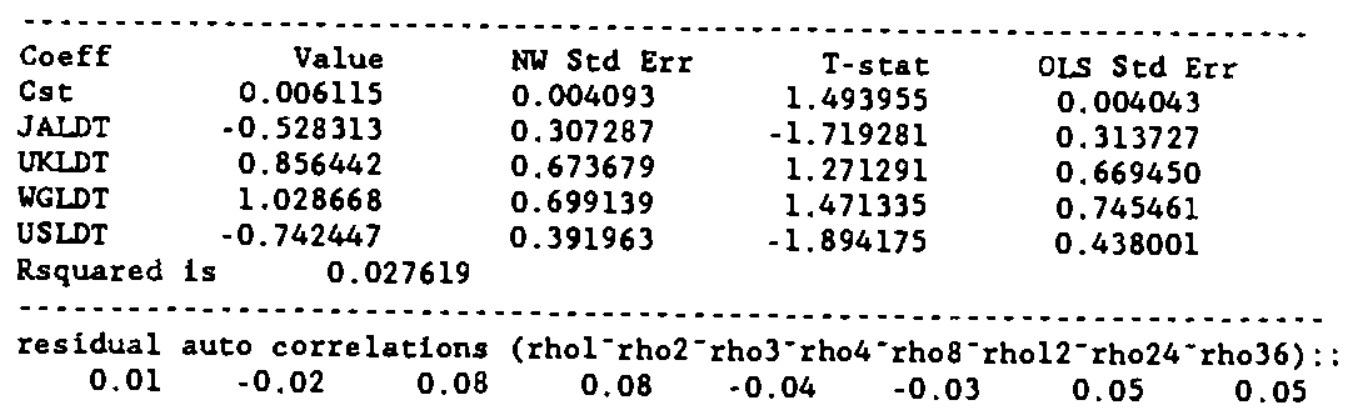

U.X. stock market

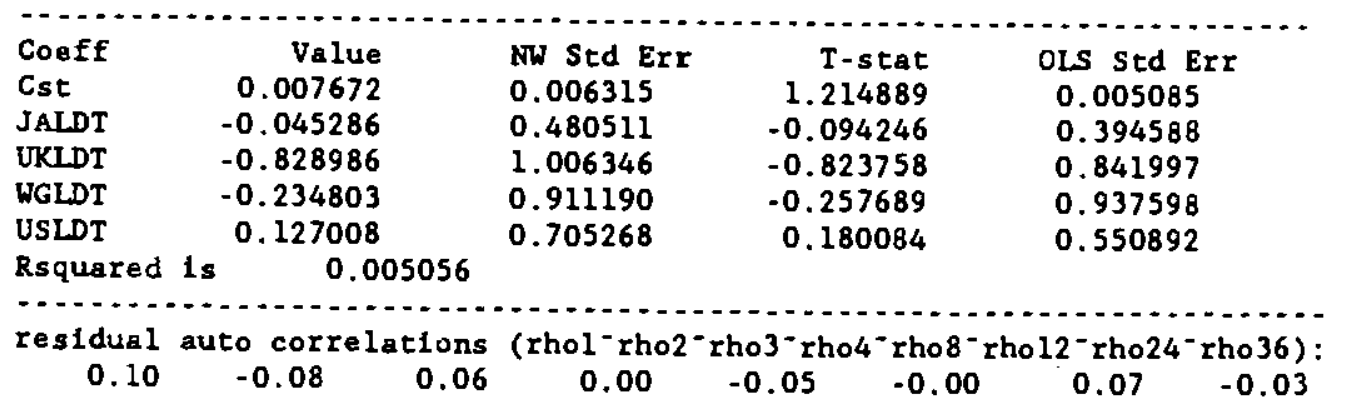


Table 9 continued

Japanese stock market

$\begin{array}{lcccc}\text { Coeff } & \text { Value } & \text { NW Std Err } & \text { T-stat } & \text { OLS Std Err } \\ \text { Cst } & 0.007704 & 0.004565 & 1.687841 & 0.004318 \\ \text { JALDT } & 0.128434 & 0.308548 & 0.416253 & 0.335046 \\ \text { UKLDT } & 0.502277 & 0.691403 & 0.726461 & 0.714943 \\ \text { WGLDT } & -0.487162 & 0.745188 & -0.653744 & 0.796118 \\ \text { USLDT } & 0.451507 & 0.458765 & 0.984179 & 0.467765\end{array}$

Rsquared is $\quad 0.008194$

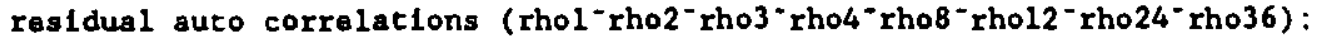
0.05
0.00
0.06
0.05
0.08
$0.08 \quad-0.02$
0.07

U.S. stock market

$\begin{array}{lcccc}\text { Coeff } & \text { Value } & \text { NW Std Err } & \text { T-8tat } & \text { OLS Std Err } \\ \text { Cst } & 0.002766 & 0.003427 & 0.807155 & 0.003064 \\ \text { JALDT } & 0.094160 & 0.240852 & 0.390946 & 0.237778 \\ \text { UKLDT } & 0.072221 & 0.450946 & 0.160154 & 0.507384 \\ \text { WGLDT } & 0.842245 & 0.582581 & -1.445712 & 0.564994 \\ \text { USLDT } & 0.247814 & 0.331390 & 0.747801 & 0.331966\end{array}$

Rsquared is

0.009287

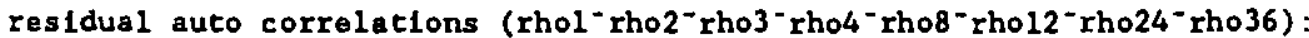
0.05
$-0.03$
0.01
0.00
$-0.00$
0.03
$-0.03$
$-0.05$

Deutschems

$\begin{array}{lcccc}\text { Coeff } & \text { Value } & \text { NW Std Err } & \text { T-stat } & \text { OLS Std Err } \\ \text { Cat } & 0.002498 & 0.002209 & 1.130873 & 0.002270 \\ \text { JALDT } & -0.093262 & 0.180581 & -0.516453 & 0.176112 \\ \text { UKLDT } & 0.345475 & 0.321228 & 1.075484 & 0.375799 \\ \text { WGLDT } & 0.344474 & 0.477226 & 0.721825 & 0.418468 \\ \text { USLDT } & -0.549694 & 0.232381 & -2.365488 & 0.245874\end{array}$

Rsquared 1s

0.022317

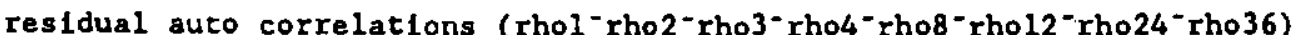
0.04
0.09
0.02
0.05
$-0.00$
0.03
0.03
0.08 
Table 9 continued Brle1sh Pound

$\begin{array}{lcccc}\text { Coeff } & \text { Value } & \text { NW Std Err } & \text { T-stat } & \text { OLS Std Err } \\ \text { Cst } & 0.002029 & 0.001968 & 1.030766 & 0.002087 \\ \text { JALDT } & 0.057912 & 0.152396 & 0.380009 & 0.161934 \\ \text { UKIDT } & -0.191978 & 0.292474 & -0.656395 & 0.345546 \\ \text { WGLDT } & 0.246833 & 0.383650 & 0.643380 & 0.384779 \\ \text { USLDT } & -0.252616 & 0.219688 & -1.149884 & 0.226080\end{array}$

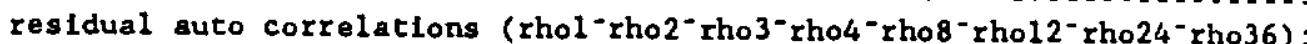
0.10
0.08
0.02
0.06
$-0.05$
$-0.00$
0.02
0.02

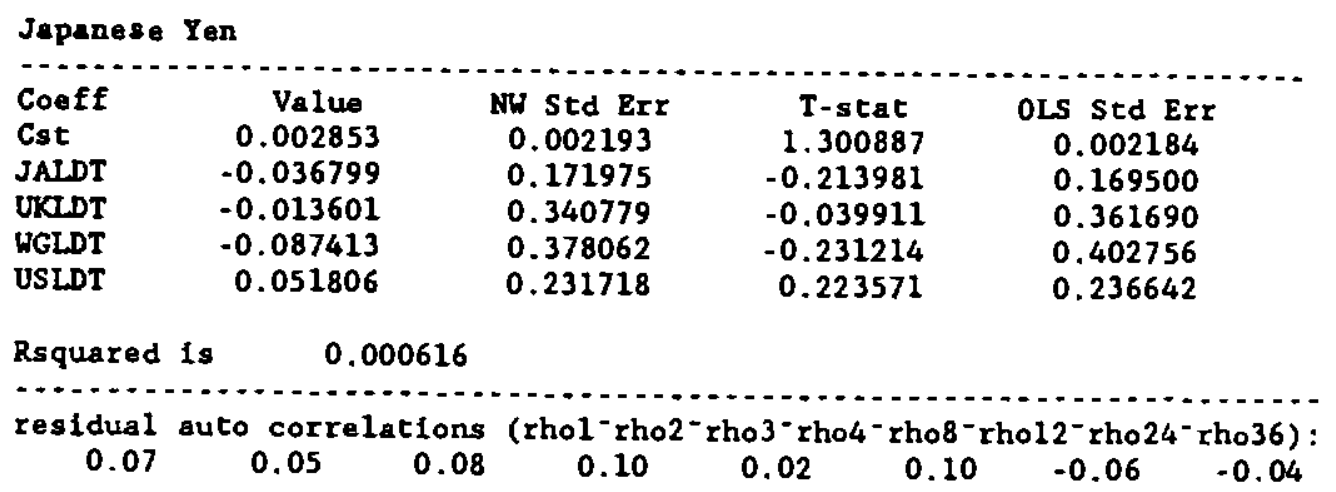

Vorld stock market

$\begin{array}{lcccc}\text { Coeff } & \text { Value } & \text { NW Std Err } & \text { T-stat } & \text { OLS Std Err } \\ \text { Cst } & 0.003171 & 0.003181 & 0.996848 & 0.002855 \\ \text { JALDT } & 0.109950 & 0.219190 & 0.501620 & 0.221523 \\ \text { UKLDT } & 0.113356 & 0.435592 & 0.260235 & 0.472700 \\ \text { WGLDT } & -0.730282 & 0.514128 & -1.420427 & 0.526371 \\ \text { USLDT } & 0.260565 & 0.325975 & 0.799338 & 0.309273\end{array}$

Rsquared is $\quad 0.009033$

residual auto correlations (rhol rho2-rho3-rho4-rho8-rho12-rho24-rho36):
0.10
$-0.03$
0.04
$-0.00$
$-0.01$
0.05
$-0.01$
$-0.03$ 


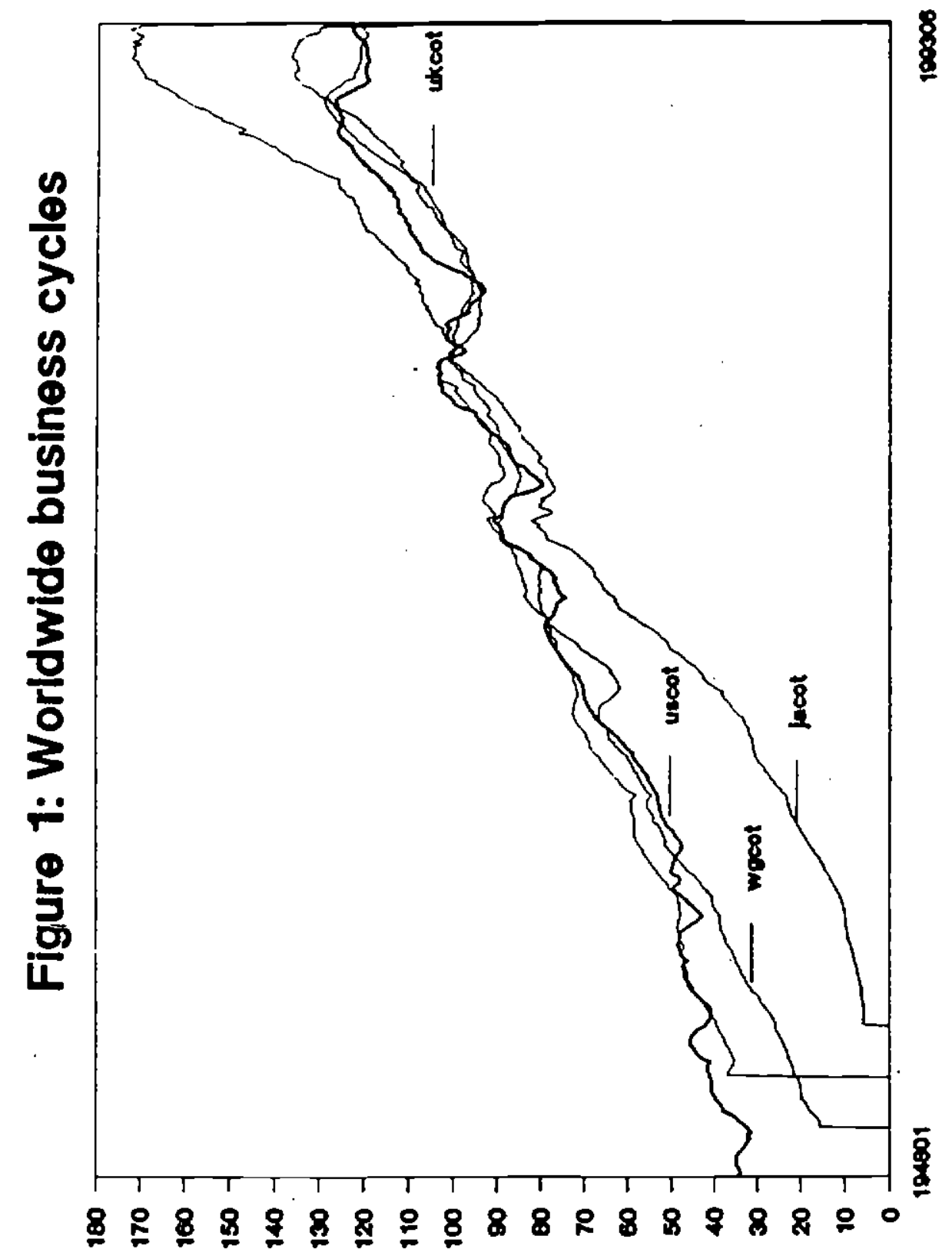




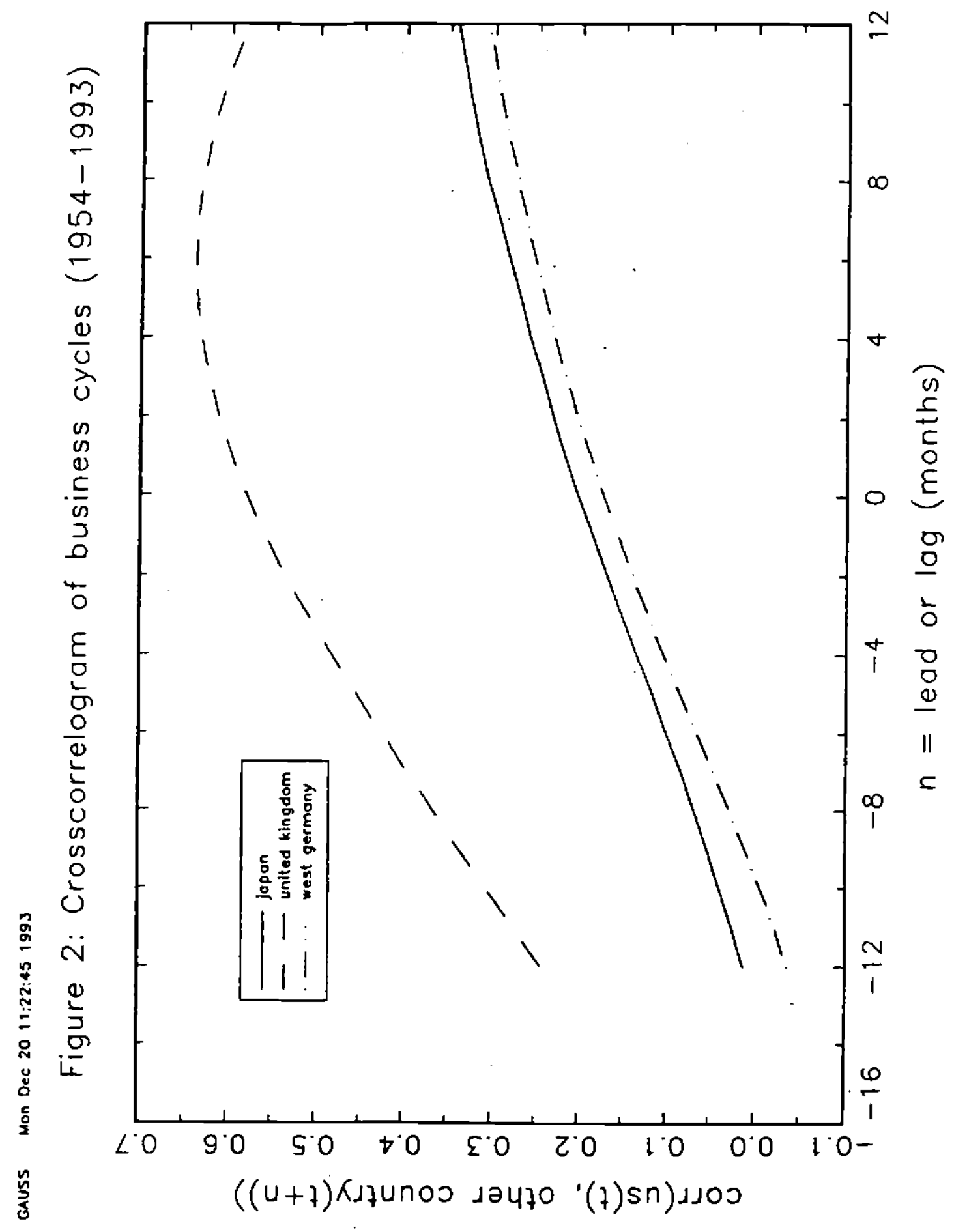

